(со. Є. Самогальська, 3. П. Мандзій, С. І. Корнага, Л. В. Радецька, Т. В. Бойко, В. А. Каплун ДВНз “Тернопільський державний медичний університет імені І. Я. Горбачевського”

\title{
ВИКОРИСТАННЯ КОМБНОВАНОГО ГЕПАТОПРОТЕКТОРА "ГЕПАДИФ" ДЛЯ КОМПЛЕКСНОГО ЛІКУВАННЯ ТА ПРОФІЛАКТИКИ ТОКСИЧНОГО ГЕПАТИТУ В ПАЦІЄНТІВ ІЗ ГЕМОБЛАСТОЗАМИ
}

\begin{abstract}
Резюме. За даними сучасних епідеміологічних і статистичних досліджень, останнім часом в Україні відзначено значне зростання частоти захворюваності на хронічну патологію печінки. Перебіг супроводжується виснаженням системи антиоксидантного захисту, на тлі якого розвивається хронічна інтоксикація з метаболічними порушеннями, що негативно впливають на функціональний стан печінки.

Мета дослідження - вивчити ефрективність комбінованого гепатопротектора “Гепадифр" в складі комплексної терапії у хворих із гемобластозами.

Матеріали і методи. Під нашим спостереженням перебувало 33 хворих із гемобластозами (3 - гострими лімфобластними лейкозами, 5 - гострими мієлобластними лейкозами, 13 - із хронічними лімфоїдними лейкеміями та 11 пацієнтів із хронічними мієлоїдними лейкеміями) віком від 32 до 67 років. Середня тривалість захворювання становила 4-6 років. Усім хворим проводили ультразвукове дослідження органів черевної порожнини (УЗД ОЧП) та біохімічні показники функції печінки, а саме, аланінамінотранссеразу, аспартатамінотрансферазу, білірубін, лужну фоссатазу, тімолову та сулемові проби.

Результати досліджень та їх обговорення. Окрім скарг основного захворювання (а це загальна слабість, недомагання, тяжкість у нижніх кінцівках, головокружіння), хворих турбувала тяжкість та відчуття розпирання у правому підребер'ї, нудота. Інколи була жовтяничність шкіри та слизових оболонок. При УзД ОЧП у 17 пацієнтів спостерігалось збільшення розмірів печінки. У середньому вона була збільшена за рахунок як правої частки, так і лівої. У 27 хворих було підвищення АЛТ та АСТ, в 11 пацієнтів також відмічалось підвищення білірубіну за рахунок непрямої фрракції. Активність процесу переважно відповідала середньому - 67,7 \% та вираженому - 22,3 \% ступенням. У процесі отримання як моно-, так і поліхіміотерапії активність вираження токсичного впливу на стан функції гепатоцитів посилювалася, на що вказувало підвищення печінкових проб. Так, показники АЛТ та АСТ підвищувалися, також спостерігалось збільшення лужної фроссратази, білірубіну за рахунок непрямої фрракції. У 8 хворих із гемобластозами була жовтячність шкіри та склер.

Висновки. У комплексному лікуванні хворих із гемобластозами обґрунтованим є застосування комбінованого препарату "Гепадиф", що має широкий спектр фармакологічної дії, а саме, детоксикаційний, антигіпоксичний, протизапальний, метаболічний ефректи його компонентів. Такий широкий спектр фармакологічної дії препарату визначив можливість використання його в комплексному лікуванні хворих із гемобластозами як для лікування токсичних гепатитів, так і його профрілактики. У пацієнтів, які отримували терапію гепадифом на тлі цитостатичної терапії, виявлено статистично достовірну нормалізацію біохімічних показників, які характеризували стан функції печінки. Корекція стану печінки дозволила провести в усіх хворих заплановане цитостатичне лікування. Після закінчення курсу моно- чи поліхіміотерапії у жодного пацієнта не відмічено погіршення функції печінки. У результаті проведеного дослідження встановлено, що в пацієнтів з онкогематологічними захворюваннями для попередження гепатотоксичності на тлі проведення хіміотерапії і для зменшення вираження вже розвинутих проявів гепатопатії необхідне долучення до протоколу лікування препаратів патогенетичної терапії синдрому цитолізу. Захисна дія комбінованого препарату "Гепадиф" дозволить зменшити кількість вимушених змін протоколів поліхіміотерапії, пов'язаних з ураженням печінки. У більшості хворих поліпшити переносимість моно- та поліхіміотерапії, підвищити якість життя пацієнтів у період лікування і реабілітації.
\end{abstract}

Ключові слова: гепадиф; токсичний гепатит; лейкоз; поліхіміотерапія.

ВстУП За даними сучасних епідеміологічних і статистичних досліджень, останнім часом в Україні відмічено значне зростання частоти захворюваності на хронічну патологію печінки. Перебіг супроводжується виснаженням системи антиоксидантного захисту, на тлі чого розвивається хронічна інтоксикація з метаболічними порушеннями, які негативно впливають на функціональний стан печінки.

Відомо, що, незалежно від етіологічного чинника (хімічні шкідливі речовини, алкоголь, радіація та ін.) в патогенетичному плані характерним є ураження мембран гепатоцитів, і як наслідок, порушення фрункції печінки, перш за все білковосинтетичної та детоксикаційної. Крім того, ушкодження печінки може бути наслідком побічної дії препаратів, які застосовуються при основній патології. А це і прийом антибіотиків, імунодепресантів, глюкокортикоїдів. На сьогодні значну роль у фрормуванні уражень фрункції печінки відіграють токсичні фрактори. Важливим фрактором впливу на фрункцію печінки $€$ використання сучасних клінічних протоколів згідно зі стандартами терапії гемобластозів. Підвищення ефективності лікування досягнуто завдяки застосуванню нових препаратів та інтенсифрікації режимів хіміотерапії. Проте негативною стороною поліхіміотерапії (ПХТ) є побічна дія протипухлинних лікарських засобів. Дані клінічних досліджень встановили, що медикаментозне ураження печінки становить близько 10 \% усіх побічних реакцій, пов'язаних із застосуванням цитостатичних препаратів $[1,5,6,10$, 12]. Насправді гепатотоксичність розвивається, мабуть, частіше, ніж свідчить офріційна медична статистика, оскільки печінка є однією з основних ланок біотрансорормації цитостатиків [2, 4].

Однією з основних причин структурно-срункціональних порушень гепатоцитів у пацієнтів онкологічного профрілю $€$ синдром ендотоксикозу, що розвивається у результаті пухлинної інтоксикації, бактерійних та вірусних інсрекцій, що приєднуються, а також унаслідок масивного лізису пухлинної тканини у відповідь на введення протипухлинних препаратів. Нині вивчено й інші механізми ушкодження печінки при прийомі лікарських препаратів, наприклад механізм імунної гепатотоксичності. Лікарська речовина або її метаболіт можуть стати гаптеном для білків печінкової паренхіми, викликаючи її імунне пошкодженн [14].

Відомо, що печінка є органом, де метаболізується більшість цитостатиків [14]. У літературі накопичилася значна кількість даних, що демонструють участь монооксигеназ печінки в їх метаболізмі. Виснаження системи цитохрому P-450, який бере участь у метаболізмі медикаментів, може призвести до зниження виведення ток- 
сичних компонентів, що надходять в організм, викликати їх накопичення в органах та тканинах, порушити знешкодження ендогенних продуктів метаболізму або спричинити утворення вторинних, іноді ще токсичніших, ніж початковий продукт, речовин. Зниження ефективності цієї ферментної системи призводить до підвищення токсичності цитостатичних препаратів [2, 3, 11, 12]. Так, за даними деяких досліджень встановлено, що цитостатичні препарати можуть у декілька разів підсилити чутливість гепатоцитів до ендотоксину [2]. Крім того, у роботах більшості дослідників доведено, що, оскільки виведення шкідливих для печінки речовин у цих умовах досить проблематичне, протипухлинні препарати можуть спричинити кумулятивну токсичну дію на її функціональний стан $[9,13,15]$.

При застосуванні протипухлинних препаратів досить часто розвивається їх гепатотоксичний ефрект, що проявляється досить широким спектром клініко-морфологічних варіантів патології печінки [4]. Зокрема, при дослідженні метотрексату виявили, що разом з ураженням печінки за типом гострого гепатиту може розвиватися печінковий фріброз різного ступеня вираження. Прояв токсичності 6-меркаптопурину характеризується некрозом й ожирінням гепатоцитів, фрормуванням фріброзу портальних трактів, холестатичним ураженням.

Токсичні гепатити можуть розвиватися внаслідок прийому циклосросфаміду (ендоксану), L-аспарагінази, ідарубіцину, а також одного із сучасних протипухлинних препаратів - талідоміду [7, 15]. У гематології застосовують також імунодепресанти, зокрема циклоспорин, які викликають токсичне ураження печінки. Поєднання різних препаратів може призводити до потенціювання їх гепатотоксичності. Так, дія на печінку 6-меркаптопурину посилюється при паралельному застосуванні доксорубіцину $[12,14]$. Тривале лікування цитостатичними препаратами може спричинити портальну гіпертензію внаслідок фрормування вираженого фріброзу.

У пацієнтів з онкопатологією можливе пострадіаційне ураження печінки, яке в гострий період може характеризуватися підвищенням рівня трансаміназ, гіпербілірубінемією (жовтяницею) та асцитом. Паралельне застосування доксорубіцину та вінкристину потенціює променеве ураження печінки. Одним із віддалених наслідків опромінення $€$ фріброз печінки. У зв'язку з широким застосуванням цитостатичних та гормональних препаратів, які мають виражену імуносупресивну дію, для лікування пацієнтів із злоякісними захворюваннями відзначають високе розповсюдження інорекційних захворювань у хворих цієї категорії. Отже, гепатити у цих пацієнтів також можуть бути зумовлені широким спектром інфекційних агентів: неспецифічними ураженнями в рамках генералізованних інфекцій, абсцесами печінки, грибковими захворюваннями та вірусними гепатитами, зокрема спричиненими цитомегаловірусами, вірусами простого й оперізувального герпесу, аденовірусами $[4,13]$.

Більшості пацієнтам призначали патогенетичне і симптоматичне лікування для попередження і лікування токсичного ураження печінки на тлі проведення цитостатичного лікування. Арсенал препаратів цілеспрямованої дії при ураженнях печінки невеликий. До них можна віднести: S-адеметіонін, урсодезоксихолеву кислоту, L-орнітин-L-аспартат і деякі інші $[15,16]$.

Для оцінки ступеня і глибини ушкодження гепатоцитів зазвичай застосовують клініко-біохімічні дослідження цілості печінкової клітини, її екскреторної активності, холестазу, фрункціональної здатності печінки, мезенхімальної та імунної реакцій. Враховуючи, що морфологічне дослідження печінки ми не проводили, то аналіз біохімічних показників, 3 певною часткою імовірності, дозволяє уточнити рівень і провідний механізм розвитку порушень функції печінки. У клінічній практиці саме змінені лабораторні показники часто $€$ відправним пунктом для проведення диференційної діагностики, визначення форми патології печінки та призначення патогенетичної терапії (табл. 1). На підставі лабораторних показників можна зробити висновок про тяжкість патологічного процесу в печінці, прогнозувати перебіг захворювання, а також оцінювати ефективність терапії, яку проводять.

Програма лікування і профрілактики гепатотоксичності у пацієнтів з онкопатологічною патологією має бути комплексною та включає:

- дієтичні заходи;

- медикаментозну терапію;

- встановлення й усунення додаткових чинників, що сприяють розвитку гепатотоксичності.

Більшості пацієнтам призначають патогенетичне і симптоматичне лікування для попередження і лікування токсичного ураження печінки на тлі проведення цитостатичного лікування. До таких препаратів відноситься гепатопротектор рослинного походження "Гепадиф". Завдяки своєму багатокомпонентному збалансованому складу препарат здатний впливати одразу на декілька патогенетичних ланок захворювання печінки. Так, карнітин, який $€$ однією з основних складових гепадифу, сприяє регенерації та проліферації гепатоцитів, запобігаючи некрозу клітин печінки, бере участь у здійсненні трансмембранного транспорту в мітохондріях високомолекулярних жирних кислот. Крім того, карнітин здатний покращувати енергетичний баланс в організмі та збільшувати його витривалість, підвищувати засвоєння протеїнів, вітамінів, вуглеводів, зберігати запас глікогену в печінці, стимулювати кровотворення та виділення кисню еритроцитами, забезпечуючи захисну дію в умовах гіпоксії [8].

Карнітину оротат проявляє і анаболічні властивості, які активують білоксинтетичні процеси, що, у свою чергу, сприяють здійсненню регенеративних властивостей та дозволяють його розглядати як засіб для оптимізації парентерального харчування [8].

До складу препарату входять також амінокислоти, які забезпечують потужну детоксикаційну дію. Наявність у складі препарату аденозину говорить про те, що гепадиф проявляє вазодилатацію, покращуючи надходження кисню до гепатоцитів, зумовлюючи антигіпоксичний ефект препарату. До складу гепадифу входить і вітамінний комплекс групи В, завдяки якому препарат бере участь у нормалізації метаболічних процесів, сприяє активації вуглеводного та ліпідного обмінів. А також бере участь в утворенні холіну, метіоніну, нуклеїнових кислот, процесах еритропоезу, покращує травлення [7, 11].

Таким чином, гепадиф нормалізує ліпідний та вуглеводний обмін, виявляє протинабрякову та мембраностабілізуючу дії, покращує детоксикаційну фрункцію печінки, виявляє антиоксидантний, антигіпоксичний та репаративний ефекти. Такий широкий спектр фрармакологічної дії препарату визначив можливість використання його в комплексному лікуванні хворих із гемобластозами як для лікування токсичних гепатитів, так і його профрілактики. 
Метою дослідження було вивчити есрективність комбінованого гепатопротектора "Гепадиф" у складі комплексної терапії у хворих із гемобластозами.

МАТЕРІАЛИ I МЕТОДИ Під нашим спостереженням перебувало 33 хворих із гемобластозами (3 - 3 гострими лімфробластними лейкозами, 5 - 3 гострими мієлобластними лейкозами, 13 - $з$ хронічними лімфоїдними лейкеміями та 11 хворих із хронічними мієлоїдними лейкеміями) віком від 32 до 67 років. Середня тривалість захворювання становила 4-6 років. Усім хворим проводили ультразвукове дослідження органів черевної порожнини (УзД ОчП) та біохімічні показники функції печінки, а саме, аланінамінотранссреразу, аспартатамінотрансореразу, білірубін, лужну фоссратазу, тимолову та сулемові проби.

Критерієм включення пацієнтів у дослідження були зміни фонкціональних печінкових проб, які були пов'язані 3 початком перебігу основного захворювання та його лікування. Лікувальний комплекс усіх пацієнтів включав прийом препаратів базисної терапії. А це прийом поліхіміотерапії, преднізолону, з подальшим зниженням дози останнього. Поряд із базисною терапією пацієнти отримували гепадиф як гепатопротектор. Препарат призначали внутрішньовенно краплинно по одному фрлакону на 400 мл 5 \% розчину глюкози (при нормальній концентрації глюкози крові у пацієнтів) протягом 5-10 днів. Після чого призначали ще по 1 капсулі двічі на день протягом 2-3 тижнів в амбулаторних умовах. Через місяць усім хворим проводили контрольне обстеження стану гепатобіліарної системи.

РЕЗУЛЬТАТИ ДОСЛІДЖЕНЬ ТА ЇХ ОБГОВОРЕННЯ Окрім скарг основного захворювання (а це загальна слабість, недомагання, тяжкість у нижніх кінцівках, голово- кружіння), хворих турбувала тяжкість та відчуття розпирання у правому підребер'ї, нудота. Інколи відмічалась жовтяничність шкіри та слизових оболонок. При УЗД ОЧП у 17 хворих спостерігалось збільшення розмірів печінки. У середньому печінка була збільшена за рахунок як правої частки, так і лівої. У 27 хворих спостерігалось підвищення АЛТ та АСТ, в 11 пацієнтів також відмічалось підвищення білірубіну за рахунок непрямої фрракції. Активність процесу переважно відповідала середньому 67,7 \% та вираженому 22,3 \% ступенням. У процесі отримання як моно-, так і поліхіміотерапії активність вираження токсичного впливу на стан функції гепатоцитів посилювався, на що вказувало підвищення печінкових проб. Так, показники АЛТ та АСТ підвищувалися, також спостерігалось підвищення лужної фроссратази, білірубіну за рахунок непрямої фрракції. У 8 хворих із гемобластозами спостерігалась жовтяничність шкіри та склер.

На основі комплексного лікування із застосуванням препарату "Гепадифр" відмічалась позитивна динаміка клінічного перебігу основного захворювання, яка проявлялася поліпшенням самопочуття хворого, загального стану, зникненням тяжкості в правому підребер'ї. Аналіз показників фрункціональних проб печінки під впливом терапії показав зниження активності запального процесу в гапатоцитах. На це вказували АЛТ, АСТ, білірубін, лужна фроссратаза (табл. ).

У хворих із мінімальною та середньою активністю ці показники поверталась до нормальних величин. А у пацієнтів із вираженою активністю дані показники зменшувались. Також встановлено позитивний вплив препарату на білковий метаболізм, про що свідчить підвищення загального білка сироватки крові.

Таблиця. Показники функції гепатоцитів до лікування цитостатиками та після отримання поліхіміотерапії і гепадифу

\begin{tabular}{|l|c|c|c|c|}
\hline \multicolumn{1}{|c|}{ Показник } & Норма & $\begin{array}{c}\text { До лікування } \\
\text { цитостатиками }\end{array}$ & $\begin{array}{c}\text { Після лікування } \\
\text { цитостатиками }\end{array}$ & $\begin{array}{c}\text { Після лікування } \\
\text { гепадисом }\end{array}$ \\
\hline Загальний білірубін (Мкмоль/л) & $<18,81$ & $21,01 \pm 0,1$ & $28,02 \pm 0,1$ & $19,03 \pm 0,1$ \\
\hline АЛТ & $<40,00$ & $53,01 \pm 0,1$ & $67,01 \pm 0,1$ & $37,00 \pm 0,1$ \\
\hline АСТ & $<40,00$ & $44,02 \pm 0,1$ & $51,01 \pm 0,1$ & $34,01 \pm 0,1$ \\
\hline ЛФ & $35-129$ & $130.01 \pm 0,1$ & $138,01 \pm 0,1$ & $87,01 \pm 0,1$ \\
\hline Загальний білок (Мкмоль/л) & $65-85$ & $62,02 \pm 0,2$ & $58,02 \pm 0,1$ & $66,02 \pm 0,1$ \\
\hline
\end{tabular}

Висновки 1. У комплексному лікуванні хворих із гемобластозами обґрунтованим є застосування комбінованого препарату “Гепадиф", який має широкий спектр фармакологічної дії, а саме, детоксикаційний, антигіпоксичний, протизапальний, метаболічний ефекти його компонентів.

2. Такий широкий спектр фрармакологічної дії препарату визначив можливість використання його в комплексному лікуванні хворих із гемобластозами як для лікування токсичних гепатитів, так і його профрілактики.

3. У пацієнтів, які отримували терапію гепадифром на тлі цитостатичної терапії, виявлено статистично достовірну нормалізацію біохімічних показників, які характеризували стан фрункції печінки. Корекція стану печінки дозволила провести в усіх хворих заплановане цитостатичне лікуван- ня. Після закінчення курсу моно- чи поліхіміотерапії в жодного пацієнта не відмічено погіршення срункції печінки.

4. Таким чином, у результаті проведеного дослідження встановлено, що в пацієнтів 3 онкогематологічними захворюваннями для попередження гепатотоксичності на тлі проведення хіміотерапії і для зменшення вираження вже розвинутих проявів гепатопатії необхідне долучення до протоколу лікування препаратів патогенетичної терапії синдрому цитолізу.

5. Захисна дія комбінованого препарату "Гепадиф" дозволить зменшити кількість вимушених змін протоколів поліхіміотерапії, пов'язаних з ураженням печінки. У більшості хворих поліпшити переносимість моно- та поліхіміотерапії, підвищити якість життя пацієнтів у період лікування і реабілітації. 


\section{СПИСОК ЛІТЕРАТУРИ}

1. Болезни печени и желчевыводящих путей / под ред.

В. Т. Ивашкина. - М., 2002. - 432 с.

2. Городецкий В. М. Осложнения противоопухолевой терапии /

В. М. Городецкий // Гематология и трансфузиология. - 1998. № 1. - С. 11-15.

3. Кан В. К. Холестаз: новое в патогенезе, диагностике и лечении / В. К. Кан // Российский журнал гастроэнтерологии, гепатологии. - 1997. - № 3. - С. 25-29.

4. Клиническая онкогематология / под ред. М. А. Волковой. - М. : Медицина, 2001. - 572 с.

5. Майер К. П. Гепатит и последствия гепатита : практическое руководство / К. П. Майер. - М., 2004. - 720 с.

6. Exadaktylos P. Acute hepatoxicity with intermediate-dose methotrexate inn children with leukemia and non-Hodgkin's lymphoma / P. Exadaktylos, T. Reiss, R. Schobess // Klin. Padiatr. - 1994. - Vol. 206. No. 4. - P. 315-318.

7. Fowler R. Thalidomide-associated hepatitis: a case report / R. Fowler, K. Imrie // Am. J. Hematol. -2001. - Vol. 66. No. 4. - P. 300-302.

8. Frezza M. The use of S-adenosyl-L-methiorline in the treatment of cholestatic disorders. A meta-analysis of clinical trials / M. Frezza, M. Terpin // Drug Invest. - 1992. - Vol. 4 (Suppl. 4). - P. 101-108.
9. Hoebe K. H. Direct cell-to-cell contact between Kupfer cells and hepatocytes augments endotoxin-induced hepatic injury / K. H. Hoebe, R. F. Witkamp, J. Fink-Gremmels // Am. J. Physiol. Gastrointest. Liver Physiol., - 2001. - Vol. 280. No. 4. - P. 720-728.

10. Jansen P. L. Intrahepatic cholestasis and biliary cirrhosis associated with extrahepatic Hodgkin's disease / P. L. Jansen, H. Van der Lelie // Neth. J. Med. - 1994. - Vol. 44. No. 3. - P. 99-102.

11. Glutathione metabolism and phisiological functions J. Vina (Eds.). Boston. - 1990. - 378 p.

12. Levis J. H. Methotrexat-induced chronic liver injury: guidelines for detection and prevention / J. H. Levis, E. Schiff // Am. J. Gastroenterol. - 1998. - Vol. 83. - P. 1337.

13. Laidlaw S. T. Fatal hepatotoxicity associated with 6-mercaptopurine therapy / S. T. Laidlaw, J. T. Reilly, S. K. Suarna // Postgrad. Med. J. - 1995. - Vol. 71. No. 849. - 639 p.

14. Santini D. S-adenosylmethionine (AdoMet) supplementation for treatment of chemotherapy-induced liver injury / D. Santini, B. Vincenzi // Anticancer Res. - 2003. - Vol. 23(6D). - P. 5173-5179.

15. Wang L. Glutathione-S-transferase enzyme expression in hema $\neg$ topoietic cell lines implies a differential protective role for $\mathrm{TI}$, and $\mathrm{Al}$ isoenzymes in erythroid and for MI in lymphoid lineages / L. Wang, J. Gloves, M. Hepburn // Haematologica, - 2000. Vol. 85. No. 6. - P. 573-579.

Отримано 12.07.17

(๖). Ye. Samogalska, Z. P. Mandzii, S. I. Kornaga, L. V. Radetska, T. V. Boyko, V. A. Kaplun

I. Horbachevsky Ternopil State Medical University

\section{THE USE OF HEPADIF COMBINED HEPATTROTECTOR FOR COMPLEX TREATMENT AND PREVENTION OF TOXIC HEPATITIS IN PATIENTS WITH HEMOBLASTOSIS}

Summary. According to the modern epidemiological and statistical studies, recently, in Ukraine, a significant increase in the incidence rate of chronic liver disease was noted. The course is accompanied by the exhaustion of the antioxidant system against to the background of chronic intoxication with metabolic disorders that adversely affect the functional state of the liver.

The aim of the study - to learn the effectiveness of the combined hepatoprotector Hepadif as a part of complex therapy in patients with hemoblastomas.

Materials and Methods. We observed 33 patients with hemoblastomas ( 3 acute lymphoblastic leukemias, 5 with acute myeloid leukemia, 13 with chronic lymphoid leukemia, and 11 patients with chronic myeloid leukemia) aged 32-67 years. The average duration of the disease was 4-6 years. All patients underwent ultrasound examination of the abdominal cavity (ultrasound examination) and biochemical parameters of the liver function, namely, alanine aminotransferase, aspartate aminotransferase, bilirubin, alkaline phosphatase, timolol and sulam samples.

Results and Discussion. In addition to complaints of the underlying disease (which is general weakness, anomalies, heaviness in the lower extremities, dizziness, mischief), the patients were concerned about the severity and sensation of dislocation in the right hypochondrium, nausea. Occasionally, jaundice of the skin and mucous membranes was observed. With ultrasound examination in 17 patients, an increase in liver size was observed. The liver was enlarged at the expense of both particles. In 27 patients, there was an increase in ALT and AST, and in 11 patients, increased bilirubin was observed due to an indirect fraction. The activity of the process mostly corresponded to an average of $67.7 \%$, and a pronounced $22.3 \%$ degree. In the process of obtaining both mono and polychemotherapy, the activity of the severity of toxic effects on the state of hepatocyte function increased, as indicated by an increase in liver samples. Thus, ALT and AST elevations were observed, as well as an increase in alkaline phosphatase, bilirubin due to an indirect fraction.

Conclutions. Thus, in the complex treatment of patients with hemoblastomas, the use of the combined preparation Hepadif, which has a wide spectrum of pharmacological action, namely detoxification, antihypoxic, anti-inflammatory, metabolic effects of its components, is substantiated. Such a wide range of pharmacological action of the drug has identified the possibility of using it in the complex treatment of patients with hemoblastomas, both for the treatment of toxic hepatitis and its prevention. In patients treated with Hepadif on the background of cytostatic therapy, a statistically significant normalization of the biochemical parameters characterizing the state of the liver function was found. Correction of the liver status allowed for all patients to have planned cytostatic treatment. At the end of the course of mono- or polychemotherapy, no liver function deterioration was observed in any patient. Thus, as a result of the study, it was found that in patients with oncohematological diseases in order to prevent hepatotoxicity against the background of chemotherapy and to reduce the severity of already developed manifestations of hepatopathy, it is necessary to add to the protocol of treatment of preparations of pathogenetic therapy of the cytolysis syndrome. The protective effect of the combined drug Hepadif will reduce the amount of forced changes in protocols of polychemotherapy associated with liver damage. In most patients, improve the tolerability of mono and polychemotherapy, improve the quality of life of patients during treatment and rehab.

Key words: Hepadif; toxic hepatitis; leukemia; poly chemotherapy. 


\section{ИСПОЛЬЗОВАНИЕ КОМБИНИРОВАННОГО ГЕПАТОПРОТЕКТОРА “ГЕПАДИФ" ДЛЯ КОМПЛЕКСНОГО ЛЕЧЕНИЯ И ПРОФИЛАКТИКИ ТОКСИЧЕСКОГО ГЕПАТИТА У ПАЦИЕНТОВ С ГЕМОБЛАСТОЗАМИ}

Резюме. По данным современных эпидемиологических и статистических исследований, в последнее время в Украине отмечен значительный рост частоты заболеваемости хронической патологии печени. Ход сопровождается истощением системы антиоксидантной защиты, на фоне которого развивается хроническая интоксикация с метаболическими нарушениями, которые негативно влияют на функциональное состояние печени.

Цель исследования - изучить эфффективность комбинированного гепатопротектора "Гепадиф" в составе комплексной терапии у больных с гемобластозами.

Материалы и методы. Под нашим наблюдением находилось 33 больных с гемобластозами (3 - с острыми лимфобластными лейкозами, 5 - с острыми миелобластными лейкозами, 13 - с хроническими лимфоидными лейкемиями и 11 больных с хронической миелоидной лейкемией) в возрасте от 32 до 67 лет. Средняя продолжительность заболевания составляла 4-6 лет. Всем больным проводилось ультразвуковое исследование органов брюшной полости (УзИ ОБП) и биохимические показатели фрункции печени, а именно, аланинаминотранссрераза, аспартатаминотрансфераза, билирубин, щелочная фоссратаза, тимолова и сулемы пробы.

Результаты исследований и их обсуждение. Кроме жалоб основного заболевания (а это общая слабость, недомогание тяжесть в нижних конечностях, головокружение), больных беспокоила тяжесть и чувство распирания в правом подреберье, тошнота. Иногда отмечалась желтушность кожи и слизистых оболочек. При УзИ ОБП у 17 больных наблюдалось увеличение размеров печени. В среднем печень была увеличена за счет как правой доли так и левой. В 27 больных было повышение АЛТ и АСТ, у 11 пациентов также отмечалось повышение билирубина за счет непрямой фрракции. Активность процесса преимущественно соответствовала среднему - 67,7 \% и выраженном - 22,3 \% степеням. В процессе получения как моно-, так и полихимиотерапии активность выраженности токсического воздействия на состояние функции гепатоцитов усиливалась, на что указывало повышение печеночных проб. Так, показатели АЛТ и АСТ повышались, также наблюдалось повышение щелочной фросфратазы, билирубина за счет непрямой фракции. В 8 больных с гемобластозами была желтушность кожи и склер. Выводы. В комплексном лечении больных с гемобластозами обоснованным является применение комбинированного препарата "Гепадиф", который имеет широкий спектр фрармакологического действия, а именно детоксикационный, антигипоксический, противовоспалительный, метаболический эсфекты его компонентов. Такой широкий спектр фармакологического действия препарата определил возможность использования его в комплексном лечении больных с гемобластозами как для лечения токсических гепатитов, так и его профилактики. У пациентов, получавших терапию гепадифом на фоне цитостатической терапии, выявлено статистически достоверную нормализацию биохимических показателей, характеризующие состояние фрункцией печени. Коррекция состояния печени позволила провести у всех больных запланировано цитостатическое лечение. После окончания курса моно- или полихимиотерапии в одного пациента не отмечено ухудшение функции печени. В результате проведенного исследования установлено, что в пациентов с онкогематологическими заболеваниями для предупреждения гепатотоксичности на фоне проведения химиотерапии и для уменьшения выраженности уже развитых проявлений гепатопатии необходимо приобщение к протоколу лечения препаратов патогенетической терапии синдрома цитолиза. Защитное действие комбинированного препарата “Гепадиср" позволит уменьшить количество вынужденных изменений протоколов полихимиотерапии, связанных с поражением печени. У большинства больных улучшить переносимость моно- и полихимиотерапии, повысить качество жизни пациентов в период лечения и реабилитации.

Ключевые слова: гепадиф; токсический гепатит; лейкоз; полихимиотерапия. 